Original Research Paper

\title{
Aktivitas Ekstrak Metanol Daun Ulin (Eusideroxylon zwageri Teijsm \& Binn) Terhadap Empat Jenis Bakteri Patogen
}

\author{
Yeni Mariani $^{1^{*}}$, Fathul Yusro ${ }^{1}$, Evy Wardenaar ${ }^{1}$ \\ ${ }^{1}$ Fakultas Kehutanan Universitas Tanjungpura, Pontianak, Indonesia
}

\author{
Riwayat artikel \\ Received : 15 Januari 2020 \\ Revised : 14 Maret 2020 \\ Accepted : 16 Maret 2020 \\ Published : 22 Maret 2020 \\ *Corresponding Author: \\ Yeni Mariani, \\ Fakultas Kehutanan \\ Universitas Tanjungpura \\ Pontianak, Indonesia \\ Email: \\ yeni.mariani81@gmail.com
}

\begin{abstract}
Abstrak: Suku Dayak Uud Danum di Kalimantan Barat memanfaatkan daun Ulin (Eusideroxylon zwageri Teijsm \& Binn) sebagai tumbuhan obat dalam pengobatan tradisional untuk mengobati berbagai penyakit seperti diare, demam dan penguat badan. Penelitian ini dilakukan untuk menganalisis aktivitas ekstrak metanol dari daun ulin terhadap beberapa jenis bakteri patogen. Daun ulin diekstraksi dengan menggunakan metanol, kemudian diuji dengan metode difusi terhadap empat jenis bakteri yaitu Enterococcus faecalis, Staphylococcus aureus, Salmonella typhi pada empat level konsentrasi (1, 5, 10 dan $15 \mathrm{mg} / \mathrm{ml})$ dan $E$. coli $(50,100,150$ dan 200 $\mathrm{mg} / \mathrm{ml})$. Hasil pengujian memperlihatkan bahwa semua level konsentrasi berpengaruh signifikan terhadap hambatan pertumbuhan bakteri patogen. Semakin tinggi konsentrasi ekstrak metanol daun ulin semakin tinggi diameter hambat yang dihasilkan. Diameter hambat tertinggi ditunjukkan oleh konsentrasi $15 \mathrm{mg} / \mathrm{ml}$ pada jenis bakteri S. typhi $(12,33 \mathrm{~mm})$ dan E. coli pada konsentrasi $200 \mathrm{mg} / \mathrm{ml}(22,67$ $\mathrm{mm}$ ). Hasil pengujian membuktikan bahwa daun ulin yang secara tradisional digunakan dalam pengobatan tradisional memiliki potensi sebagai antibakteri alami.
\end{abstract}

Kata kunci: Ulin, antibakteri, Enterococcus faecalis, Staphylococcus aureus, Salmonella typhi, dan Escherichia coli.

Abstract: Dayak Uud Danum of West Kalimantan traditionally use ulin leaves (Eusideroxylon zwageri Teisjm \& Binn) to cure various diseases namely diarrhea, fever, and tonic. This present study aims to evaluate the activity of methanol extract of ulin leaves against several types of pathogenic bacteria. Ulin leaves were extracted with methanol; thus, the extract resulted tested in terms of disc diffusion Kirby and Bauer against four types of bacteria such as Enterococcus faecalis, Staphylococcus aureus, Salmonella typhi (1, 5, 10, and $15 \mathrm{mg} / \mathrm{ml}$ ), and Escherichia coli $(50,100,150$, and $200 \mathrm{mg} / \mathrm{ml})$. The results showed that all levels of concentration significantly affect the inhibition growth of pathogenic bacteria. The higher the concentration of methanol extract of ulin leaves used, the higher the inhibition zone produced. The highest response inhibition growth showed from the highest level of $15 \mathrm{mg} / \mathrm{ml}$ on S. tyhpi $(12.33 \mathrm{~mm})$, and E. coli was $200 \mathrm{mg} / \mathrm{ml}(22.67 \mathrm{~mm})$. It suggested that the leaves of ulin which traditionally used as medicinal plant have the potency as natural antibacterial agents.

Keywords: Ulin, antibacterial, Enterococcus, faecalis, Staphylococcus aureus, Salmonella typhi, and Escherichia coli.

\section{Pendahuluan}

Masyarakat di negara berkembang sering mengalami penyakit klinik yang hampir 50\% diantaranya disebabkan oleh infeksi mikroba (Elisha et al. 2017). Bakteri seperti Entrococus faecalis, Salmonela typhi, Staphylococcus aureus, dan E. coli adalah jenis mikroba patogen yang menjadi penyebab beberapa penyakit seperti diare, inflammasi, penyakit kulit, infeksi saluran pernapasan, infeksi saluran kencing dan masih banyak penyakit lainnya (Primawati et al. 2013; Kurniawan et al. 2019; Prihatiningtyas et al. 2018; Hidayat et al. 2019). Untuk mengatasi serangan penyakit 
tersebut digunakan antibiotik yang umum digunakan dalam dalam dunia pengobatan modern.

Saat ini penggunaan antibiotik modern menghadapi fenomena resistensi terhadap antibiotik modern yang ditunjukkan oleh beberapa bakteri patogen seperti Escherichia coli (Sen et al. 2019). Keberadaan enzim $\beta$-lactamase yang dimiliki oleh $E$. coli menyebabkan bakteri ini resisten terhadap penisilin, cepalosporin dan monobactam aztreonam (Pormohammad et al. 2019). Peningkatan resistensi bakteri terhadap antibiotik membuka peluang untuk ditemukannya obat-obatan baru yang efektif dan mampu untuk mengatasi infeksi bakteri, terutama pada negeranegara berkembang seperti Indonesia. Sehingga penting untuk dilakukan pencarian sumber antibakteri baru yang berasal dari bahan alam.

Dzoyem et al. (2017) menyatakan bahwa ekplorasi tanaman obat adalah salah satu cara untuk menemukan tumbuhan obat yang berpotensi sebagai antibakteri, hal ini dukung oleh fakta bahwa masyarakat tradisional telah memiliki sejarah panjang di dalam menggunakan tumbuhan obat dalam mengobati berbagai penyakit yang disebabkan oleh bakteri patogen. Berkaitan dengan perkembangan industry farmasi telah meningkatkan pemanfaatan tumbuhan yang mengandung obat-obatan untuk diisolasi senyawa aktifnya (Ahmed $e t$ al. 2014). Saat ini, sekitar $25 \%$ dari obat sintesis yang komersilkan adalah berasal dari tumbuhan obat (Coxti, 2019). Menurut Raja et al. (2011) tercatat 1600 jenis obat modern yang beredar di pasaran berasal dari tumbuhan obat.

Tumbuhan obat memiliki fungsi yang cukup vital karena khasiatnya untuk pengobatan secara tardisional dan modern, selain itu dapat pula digunakan sebagai antibiotik alami untuk mengatasi serangan mikroorganisme seperti bakteri (Al-Kattan dan Khayyat, 2017). Perkembangan ilmu pengetahuan telah menghasilkan beberapa penelitian berkaitan dengan tumbuhan obat. Dilakukannya pengujian terhadap kemampuan senyawa yang terkandung pada tumbuhan seperti alkaloid, fenolik, terpenoid, steroid dan senyawa lainnya senyawa terbukti dapat mengatasi bakteri patogen yang dapat menyebabkan berbagai penyakit (Mathur, 2013; Saleem et al. 2010; Khameneh et al. 2019).

Ulin (E. zwageri) sebagai salah satu jenis tumbuhan asli Kalimantan digunakan oleh masyarakat Dayak Uud Danum yang tinggal di sekitar Sungai Ambalau Kecamatan Ambalau Kabupaten Sintang Kalimantan Barat sebagai obat tradisional. Suku Dayak Uud Danum menggunakan daun ulin untuk mengobati penyakit demam, penguat badan (tonik), sakit perut, alergi dan perawatan setelah melahirkan (Mariani et al. 2016). Berkaitan dengan hal ini, informasi tentang bioaktivitas antibakteri dari tanaman ulin masih sangat terbatas. Salah satu informasi yang telah dipublikasi adalah aktivitas bakteri dari ulin hanya pada bagian batang dan kayunya, sedangkan bagian lainya seperti bagian daun belum dieksplorasi tentang aktivitas antibakterinya. Darussalam (2016) menyatakan ekstrak kayu ulin pada uji dengan $S$. aureus menunjukkan hambatan pertumbuhan sebesar $14,8 \mathrm{~mm}$ dengan tingkat konsentrasi $100 \%$. Wila et al. (2018) melaporkan kemampuan ekstrak etanol kulit batang ulin dalam menghambat bakteri S. typhi $(15 \mathrm{mg} / \mathrm{ml}$ dengan diameter hambatan 14,33 mm), dan bakteri E. coli (200 mg.ml dengan diameter hambatan $(24,33 \mathrm{~mm})$.

Melihat potensi akan besarnya kemampuan Ulin sebagai tumbuhan obat untuk mengobati penyakit yang disebabkan oleh bakteri patogen, maka perlu dilakukannya pengujian terkait aktivitas antibakteri dari ekstrak metanol daun Ulin. Aktivitas antibakteri ini dapat dilakukan dengan metode difusi sehingga didapatkan diameter zona hambat (Balouiri et al. 2016). Melalui penelitian ini diharapkan mampu memperkaya ilmu pengetahuan mengenai alternatif antibiotik alami dalam mengobati penyakit yang disebabkan oleh bakteri patogen.

\section{Bahan dan Metode}

\section{Bahan}

Daun ulin (E. zwageri), metanol, plate count agar (PCA), aquades, larutan $\mathrm{H}_{2} \mathrm{SO}_{4} \quad 1 \% \quad 0,1 \mathrm{~mL}$ larutan $\mathrm{BaCl} 2$ 1,175\%. Bakteri S. aureus, E. faecalis. S. typhi dan E. coli.

\section{Metode \\ Persiapan Sampel}

Daun ulin (E. zwageri) berasal dari pohon ulin yang berasal dari Kecamatan Bengkayang Kabupaten Landak. Daun ulin yang segar dipisahkan dari bagian tangkai daun dan ranting dengan menggunakan gunting dan parang. Daun tersebut selanjutnya dibersihkan dari debu dan kotoran yang menempel. Setelah bersih, daun ulin kemudian dikeringkan dibawah naungan selama beberapa hari. Selanjutnya, daun ulin tersebut dipotong kecil untuk mempermudah dalam proses pembuatan serbuk yang akan dilakukan dengan blender. Serbuk ulin yang diperoleh kemudian disaring (serbuk lolos 40 mesh tertahan 60 mesh).

\section{Maserasi}

Sebanyak $800 \mathrm{~mL}$ metanol $96 \%$ dimasukkan ke dalam wadah berupa botol reagen yang telah berisi $200 \mathrm{~g}$ serbuk daun ulin (perbandingan 1:4) kemudian dihomogenkan (24 jam), selanjutnya disaring dengan kertas saring (merk Whatman No. 42) dan filtratnya dimasukkan kembali ke dalam Erlenmeyer $1000 \mathrm{~mL}$. Residu kembali di maserasi lagi seperti perlakuan awal 
kemudian disaring kembali dan ditambahkan ke dalam Erlenmeyer $1000 \mathrm{~mL}$ yang telah ditampung filtratnya, perlakuan tersebut diulang hingga diperoleh filtrat agak jernih. Setelah itu, filtrat dimasukkan ke dalam labu evaporator yang telah ditimbang beratnya. Selanjutnya, filtrat yang diperoleh dengan evaporator pada suhu 40$55^{\circ} \mathrm{C}$ diuapkan untuk menghilangkan pelarut sisa hingga diperoleh ekstrak daun Ulin yang pekat. Ekstrak hasil evaporasi selanjutnya di timbang dan disimpan dalam desikator sebelum digunakan untuk pengujian lanjutan.

\section{Pembuatan Media Plate Count Agar (PCA)}

$17,5 \mathrm{~g}$ serbuk plate count agar didispersikan dengan aquadest steril hingga mencapai volume 1000 $\mathrm{mL}$. Selanjutnya medium tersebut didihkan di atas penangas air hingga larut sepenuhnya. Medium tersebut selanjutnya disterilkan di dalam autoclave dengan tekanan 1 atm (temperatur $121^{\circ} \mathrm{C}$ ), proses ini berlangsung selama 15 menit pada tekanan 1 atm.

\section{Penyiapan Larutan Mc. Farland}

Larutan Mc. Farland merupakan standar yang digunakan untuk kekeruhan suspense bakteri uji. Pada penelitian ini, digunakan standar Mc. Farland I dengan suspensi bakteri uji sebanding dengan konsentrasi 300x $10^{6} \mathrm{CFU} / \mathrm{ml}$. Larutan Mc. Farland I ini dibuat dengan melarutkan 9,9 mL larutan $\mathrm{H}_{2} \mathrm{SO}_{4} 1 \%$ dengan 0,1 $\mathrm{mL}$ larutan $\mathrm{BaCl} 21,175 \%$ ke dalam tabung reaksi. Selanjutnya campuran larutan tersebut dikocok hingga terbentuk larutan yang keruh.

\section{Uji Aktivitas Antibakteri}

Disc diffusion Kirby and Bauer atau dikenal dengan nama metode difusi digunakan dalam penelitian ini untuk menganalisa kemampuan dari ekstrak metanol daun ulin dalam menghambat pertumbuhan 4 jenis bakteri. Media PCA yang telah disterilkan (5-6 ml) dimasukkan ke dalam cawan petri hingga memadat. Isolat bakteri dalam bentuk agar dimasukkan ke dalam tabung reaksi secara hati-hati dengan menggunakan jarum ose yang telah disterilkan, kemudian ditambahkan beberapa larutan buffer dan dihomogenkan. Selanjutnya, suspensi bakteri tersebut diamati hingga mencapai kekeruhan yang disetarakan dengan larutan Mc. Farland 1 sebagai standar kekeruhannya. Suspensi bakteri tersebut kemudian dipindahkan ke cawan petri yang telah berisikan media PCA dengan menggunakan jarum ose steril.

6 helai kertas cakram kosong (Oxoid, Inggris) yang berukuran diameter $6 \mathrm{~mm}$ ditetesi sebanyak $10 \mu \mathrm{L}$ masing-masing konsentrasi uji dan didiamkan selama beberapa menit agar pelarutnya menguap. Selanjutnya secara berhati-hati dengan menggunakan pinset steril, kertas cakram tersebut kemudian diletakkan pada petri dish yang telah terdapat sebaran biakan bakteri. Untuk memperoleh kertas cakram yang menempel dengan baik pada permukaan media, kertas cakram harus ditekan dengan pelan. Selanjutnya selama 24 jam, biakan yang berada di petri dish diinkubasi pada laminar air flow (temperatur $30^{\circ} \mathrm{C}$ ). Pada setiap bakteri uji diberikan 4 level konsentrasi ekstrak metanol daun ulin. Pada penelitian ini digunakan metanol sebagai kontrol negatif dan tetracycline sebagai kontrol positif.

Penggunaan metanol sebagai kontrol negatif dikarenakan metanol merupakan pelarut yang digunakan dalam proses maserasi maserasi daun ulin (E. zwageri), sedangkan tetracycline dipilih karena merupakan antibiotik yang umum digunakan dalam mengatasi infeksi bakteri, selain itu antibiotik ini memiliki harga yang murah serta terjangkau oleh masyarakat.

Rancangan acak lengkap (RAL) digunakan dalam penelitian ini dengan 3 kali ulangan. Nilai aktivitas antibakteri diperoleh dengan mengukur diameter hambatan yang terbentuk selama ekstrak berdifusi. Daerah hambatan tersebut berupa daerah bening (clear zone) tersebut diukur dengan menggunakan penggaris/jangka sorong.

\section{Hasil dan Pembahasan}

\section{Aktivitas antibakteri}

Pengujian aktivitas antibakteri merupakan suatu cara untuk menguji kemampuan suatu senyawa kimia dalam menghambat pertumbuhan bakteri. Pengujian aktivitas antibakteri ekstrak metanol daun ulin dilakukan pada dua kelompok bakteri (Gram positif dan negatif). $S$. aureus dan E. faecalis merupakan bakteri Gram positif sedangkan bakteri Gram negatif yang diujikan dalam penelitian ini yaitu $S$. typhi dan E. coli.

Meskipun konsentrasi ekstrak yang digunakan cukup rendah yaitu 1, 5, 10 dan $15 \mathrm{mg} / \mathrm{ml}$, ekstrak metanol daun ulin menunjukkan aktivitas yang tinggi dalam penghambatan pertumbuhan bakteri $S$. aureus dan E. faescalis dengan diameter zona hambat berkisar 6,8313,67 mm (Gambar 1 dan 2) dengan konsentrasi 15 $\mathrm{mg} / \mathrm{ml}$ memberikan diameter zona hambat terbesar. Diameter hambatan yang dihasilkan pada pengujian bakteri $S$. aureus ini lebih besar daripada dengan zona hambat hasil penelitian Darussalam (2016) yang menggunakan ekstrak etanol batang ulin dan pada konsentrasi yang lebih tinggi (20, 40, 60, 80 dan 100\%) memperoleh diameter zona hambat $8,8 \mathrm{~mm}-14,8 \mathrm{~mm}$.

Pada penelitian ini selain menggunakan bakteri uji jenis Gram positif, digunakan pula bakteri uji jenis gram negatif yaitu $S$. tyhpi dan E. coli. Bakteri $S$. typhi dan bakteri $E$. coli merupakan mikroba patogen yang dapat menyebabkan infeksi pada manusia dan hewan. S.typhi merupakan penyebab demam tifus sedangkan diare dapat disebabkan oleh adanya infeksi dari E. coli. Selain itu, kedua jenis bakteri ini menjadi penyebab 
terjadinya keracunan makanan (food poisoning) (Mostafa et al., 2018).

Pada penelitian ini kontrol negatif tidak terbentuk daerah hambatan atau zona bening (Gambar 1 dan 3), hal ini berarti bahwa pelarut metanol yang digunakan dalam proses ekstraksi tidak beracun bagi bakteri uji. Menurut Demirel et al. (2009), pelarut metanol yang sering digunakan dalam ekstraksi bahan alam tidak memiliki sifat antibakteri, sehingga hasil nilai hambatan yang diperoleh dalam pengujian ini merupakan aktivitas senyawa metabolit sekunder yang dikandung oleh ekstrak daun ulin (E. zwageri).

Pada penelitian ini digunakan juga tetracycline sebagai kontrol positif. Pada Gambar 1 dan 3 terlihat dengan jelas bahwa antibiotik tetracycline $(30 \mu \mathrm{g})$ merupakan jenis antibiotik yang mampu mengatasi infeksi bakteri, hal ini dibuktikan dengan terbentuknya zona hambatan maksimum yaitu sebesar $25 \mathrm{~mm}$ pada kesemua jenis bakteri uji. Grossman (2016) mengemukakan bahwa tetracycline merupakan jenis antibiotik yang memiliki aktivitas dengan spektrum yang luas. Antibiotik ini mampu menghambat pertumbuhan mikroba baik itu bakteri Gram positif dan negatif serta parasit protozoa.
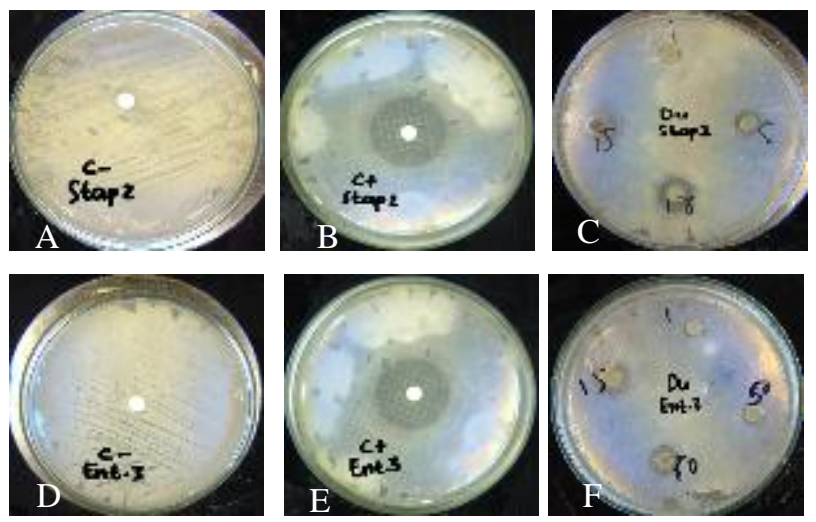

Gambar 1. Daya hambat ekstrak methanol daun ulin $(E$. zwageri) terhadap pertumbuhan $S$. aureus dan E. faecalis (A dan D: Kontrol negatif (metanol 96\%); B dan E: Kontrol positif (tetracycline $30 \mu \mathrm{g}) ; \mathrm{C}$ dan $\mathrm{E}$ : ekstrak dengan 4 level konsentrasi $(1,5,10$, dan 15 $\mathrm{mg} / \mathrm{ml}$ )

Secara umum, bakteri Gram positif memiliki resistensi alami yang lebih lemah daripada bakteri Gram negatif. Bagian dinding sel bakteri Gram positif atau dikenal dengan istilah peptidoglikan merupakan lapisan makromolekul yang tersusun atas teichoic acid, teichuronic acid, polifospat dan karbohidrat. Pada bakteri gram positif, lapisan peptidoglikan yang berfungsi sebagai penutup dan pelidung sel bakteri ini lebih rendah kepadatannya dibandingkan pada jenis bakteri Gram negatif, hal ini karena pada lapisan luarnya tidak diselimuti dengan membran luar seperti pada bakteri gram negative (Lehman dan Grabowicz, 2019).

Kurang padatnya lapisan struktur pada dinding sel bakteri Gram positif daripada yang terdapat pada jenis bakteri Gram negatif diduga menjadi penyebab senyawa metabolit sekunder tumbuhan yang berperan sebagai antibakteri alami dapat berpenetrasi dengan mudah ke dalam tubuh bakteri gram positif sehingga menunjukkan daya hambat yang besar. Hal yang sama juga dinyatakan oleh May dan Grabowicz (2018), sedangkan jika ekstrak dalam konsentrasi yang tinggi akan membuat protein sitoplasma terdenaturasi dan akan menyebabkan kematian dari sel.

Pada tahap awal uji aktivitas antibakteri, diberikan ekstrak metanol daun ulin pada konsentrasi dibawah $50 \mathrm{mg} / \mathrm{ml}$, akan tetapi pada konsentrasi tersebut tidak menunjukkan hambatan pertumbuhan. Oleh karena itu untuk melihat aktivitas antibakteri dari ekstrak metanol daun ulin, level konsentrasi yang diberikan kepada bakteri uji ini ditingkatkan menjadi 50, 100, 150, dan $200 \mathrm{mg} / \mathrm{ml}$ (Gambar 3).

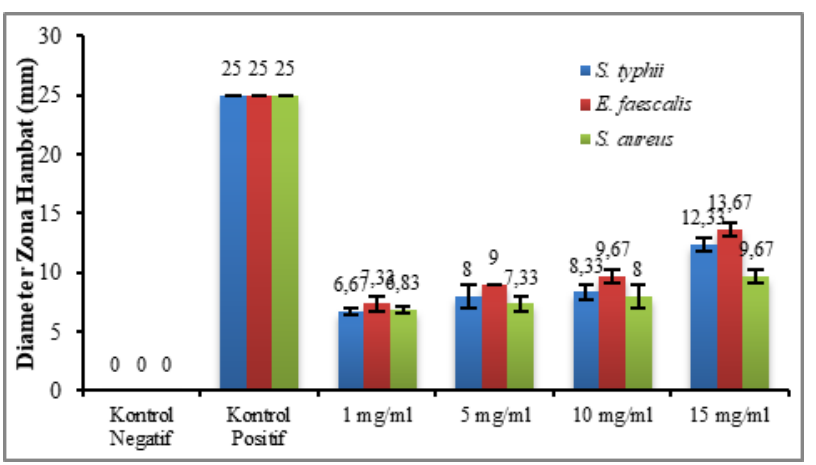

Gambar 2. Nilai diameter zona hambatan pertumbuhan bakteri E. faescalis, S. aureus dan S. typhi oleh ekstrak metanol daun ulin (E. zwageri) pada beberapa tingkat konsentrasi dan pada kontrol negatif dan positif.

Sedangkan untuk bakteri $S$. typhi walaupun bakteri ini juga merupakan bakteri Gram negatif, akan tetapi konsentrasi yang digunakan sama dengan konsentrasi yang diberikan pada bakteri Gram positif (Gambar 2 dan 3).

Bakteri Gram negatif mempunyai karakter yang berbeda dibandingkan dengan bakteri Gram positif. Perbedaan ini berdasarkan pada kompleksitas struktur dinding sel yang dimiliki oleh bakteri Gram negatif. Bakteri Gram negatif memiliki peptidoglikan yang tebal dengan ketebalan berkisar 2-3 nm atau $20 \%$ dari bobot kering dinding sel. Pada bagian terluar dari lapisan peptidoglikan terdapat membran luar (OM) (May dan Grabowicz, 2018). 
Tingginya konsentrasi yang aplikasikan pada Bakteri E. coli diduga disebabkan karena bakteri ini memiliki resistensi alamiah yang tinggi. Resistensi ini memungkinkan bakteri E. coli untuk tahan terhadap aktivitas antibakteri yang diberikan padanya. Adanya resistensi ini disebabkan karena kemampuan bakteri $E$. coli dalam menghancurkan antibiotik tersebut dengan menghasilkan beta-laktamase ( $\beta$-lactamase) sebagai mediator dalam penghambatan aktivitas antibiotik. $\beta$ laktamase yang tersusun atas berbagai enzim ini kemudian didistribusikan secara merata keseluruh bagian bakteri sehingga tubuh bakteri dapat terlindungi dari kerusakan yang disebabkan oleh aktivitas antibiotik (Allocati et al. 2013).

Nilai hambatan pertumbuhan bakteri E. coli tertinggi dihasilkan dari penggunaan konsentrasi ekstrak daun ulin sebesar $200 \mathrm{mg} / \mathrm{ml}$ yang menghasilkan diameter hambatan sebesar $22,7 \mathrm{~mm}$, sedangkan nilai hambatan terendah ditunjukkan dari konsentrasi ekstrak $50 \mathrm{mg} / \mathrm{ml}(6,83 \mathrm{~mm})$ (Tabel 2).
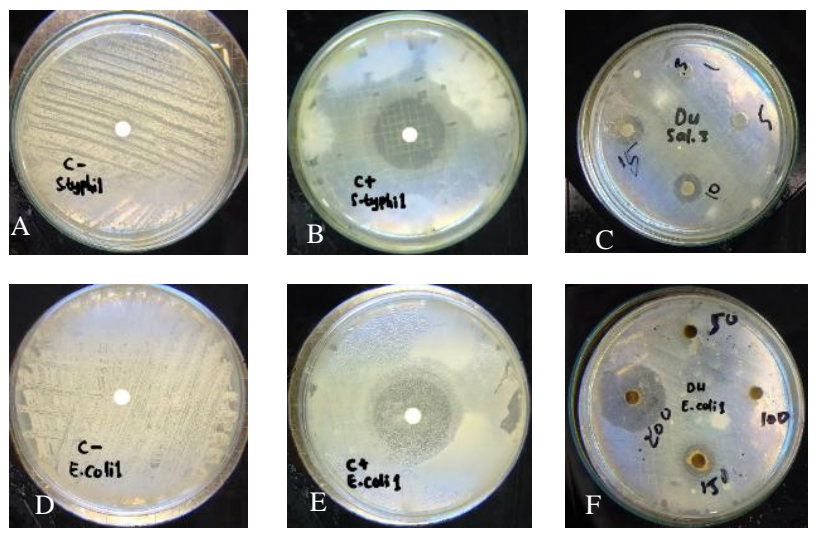

Gambar 3. Daya hambat ekstrak metanol daun ulin $(E$. zwageri) terhadap pertumbuhan S. tyhpi dan E. coli (A dan D: Kontrol negatif (metanol 96\%); B dan E: Kontrol positif (tetracycline $30 \mu \mathrm{g}$; $\mathrm{C}$ dan $\mathrm{E}$ : ekstrak dengan 4 level konsentrasi $(1,5,10$, dan $15 \mathrm{mg} / \mathrm{ml})$

Nilai hambatan tertinggi yang ditunjukkan oleh ekstrak pada bakteri $S$. tyhpi dihasilkan dari penggunaan konsentrasi $15 \mathrm{mg} / \mathrm{ml}(12,33 \mathrm{~mm})$ dan hambatan terendah dihasilkan oleh penggunaan konsentrasi 1 $\mathrm{mg} / \mathrm{ml}(6,67 \mathrm{~mm})$.

Lapisan membran luar dan lapisan peptidoglikan terhubung dengan lipoprotein yang dikenal dengan nama "Lipoprotein Braun". Lapisan terluar inilah yang menjadi salah satu karakter pembeda antara kedua kelompok bakteri. Membran luar ini tersusun atas 2 lapisan fospolifid (lapisan ganda) yang terhubung dengan membran luar oleh lipopolisakarida. Oleh karena itu, bakteri Gram negatif memiliki resistensi alami terhadap antibakteri karena lapisan peptidoglikan yang terdapat pada bakteri ini terlindungi oleh membrane luar. Menurut Nazzaro et al., (2013), antibakteri alami hanya akan dapat masuk melewati membran luar dalam jumlah yang kecil saja, akan tetapi bukan berarti bahwa lapisan membran luar ini tidak dapat ditembusi oleh molekul hidrofobik, senyawa antibakteri akan dapat menembus walaupun memerlukan waktu yang cukup lama.

Pada Tabel 2 terlihat jelas bahwa meskipun bakteri $S$. typhi dan E. coli memiliki resistensi alami yang cukup tinggi, ekstrak methanol daun ulin diduga mampu berpetrasi ke dalam peptidoglikan dan menembus membrane luar. Hal ini terlihat dari tingginya diameter zona hambat yang dihasilkan sehingga respon hambatan pertumbuhan yang ditunjukkan juga tergolong kuat hingga sangat kuat.

Tinggi rendahnya respon hambatan pertumbuhan ini diduga ditentukan oleh kenaikan konsentrasi. Kenaikan konsentrasi dari ekstrak metanol daun ulin diikuti pula dengan kenaikan diameter zona hambat pertumbuhan bakteri.

Pada bakteri E. coli, zona hambatan yang terbentuk dengan pemberian ekstrak daun ulin pada konsentrasi $200 \mathrm{mg} / \mathrm{ml}$ bahkan hampir menyamai diameter hambat yang ditunjukkan oleh tetracyclin (25 $\mathrm{mm})$ sebagai kontrol positif yang merupakan obat modern dan memiliki aktivitas antibakteri dengan spectrum luas. Zona hambat yang diperlihatkan oleh ekstrak metanol daun ulin lebih tinggi dibandingkan dengan dihasilkan oleh ekstrak etanol buah kesemek $(8,8$ $\mathrm{mm}$ ) pada konsentrasi yang lebih tinggi (100\%) (Wau et al. 2019). Nazzaro et al. (2013) yang menyatakan bahwa ekstrak dapat berpenetrasi dalam jumlah besar kedalam dinding sel bakteri gram positif karena keberadaan struktur dinding selnya yang bersifat hidrofobik. Ekstrak yang telah berpenetrasi ke dalam dinding sel ini kemudian berinteraksi dengan sitoplasma sel. Apabila ekstrak tersebut dalam konsentrasi yang rendah akan menggangu metabolisme sel dalam pembentukan energy dengan cara mengganggu kerja enzim.

Ekstrak metanol daun ulin terbukti memiliki kemampuan untuk menghambat pertumbuhan $E$. coli. Ekstrak metanol daun ulin diduga memiliki komponen kimia seperti alkaloid, flavonoid, steroid, fenolik dan saponin yang juga dimiliki oleh ekstrak bagian batang ulin (Wila et al. 2018). Menurut Radulovic et al. (2013), senyawa-senyawa tersebut yang pada umumnya dimiliki oleh tumbuhan memiliki pengaruh terhadap pertumbuhan bakteri atau dapat berperan sebagai antibakteri.

Ada beberapa mekanisme kerja dari senyawa metabolit sekunder sebagai antibakteri dalam menghambat pertumbuhan bakteri atau membunuh bakteri, yaitu (1) dengan mempengaruhi protein pada 
dinding sel bakteri yang kemudian diikuti dengan terganggunya perpindahan molekul pada sel bakteri; (2) dengan cara mempengaruhi stabilitas dari lapisan ganda fosfolipid yang diikuti dengan hancurnya membran plasma serta menonaktifkan enzim metabolisme sel bakteri. Penghambatan transport elektron dan menggangu perpindahan proton, translokasi protein dan sintesis komponen sel merupakan perubahan fisik yang dapat mengakibatkan kematian atau kehancuran dari sel bakteri (Nazzaro et al. 2013; Lobritz et al. 2015).

Tabel 2. Respon hambatan aktivitas antibakteri ekstrak metanol daun ulin

\begin{tabular}{lccc}
\hline Bakteri & $\begin{array}{c}\text { Konsentrasi } \\
(\mathrm{mg} / \mathrm{ml})\end{array}$ & $\begin{array}{c}\text { Diameter } \\
\text { Zona } \\
\text { Hambat } \\
(\mathrm{mm})\end{array}$ & $\begin{array}{c}\text { Respon } \\
\text { Hambatan } \\
\text { Pertumbuhan }\end{array}$ \\
\hline E. & 1 & 7,33 & Sedang \\
faescalis & 5 & 9 & Sedang \\
& 10 & 9,67 & Sedang \\
S. aureus & 15 & 13,67 & Kuat \\
& 1 & 6,83 & Sedang \\
& 5 & 7,33 & Sedang \\
S. typhi & 10 & 8 & Sedang \\
& 15 & 9,67 & Sedang \\
& 1 & 6.67 & Sedang \\
& 5 & 8 & Sedang \\
E. coli & 10 & 8,33 & Sedang \\
& 15 & 12,33 & Kuat \\
& 50 & 6,83 & Sedang \\
& 100 & 8,33 & Sedang \\
& 150 & 13,33 & Kuat \\
& 200 & 22,67 & Sangat Kuat \\
\hline
\end{tabular}

Sejak turun temurun, ulin adalah salah satu jenis tumbuhan obat yang telah digunakan oleh suku Dayak Uud Danum di Kalimantan Barat. Secara tradisional, daun ulin selain digunakan untuk mengobati penyakit seperti demam, sakit perut dan diare, daun ulin juga digunakan sebagai penambah stamina atau tonik. Mariani et al. (2016) melaporkan aktivitas anti-inflamasi ekstrak methanol daun ulin dalam mengatasi delayedtype hypersensitivity (DTH) dan inflamasi pada epithelial sel. Ekstrak daun ulin terbukti memiliki kemampuan untuk menghambat pertumbuhan bakteri $E$. coli dan $S$. typhi yang termasuk ke dalam golongan bakteri Gram negatif dan juga mampu menghambat pertumbuhan bakteri $S$. aureus dan E. faescalis sebagai golongan bakteri Gram positif. Daun ulin diduga mengandung berbagai komponen kimia seperti fenolik, flavonoid, alkaloid, saponin dan terpenoid yang telah terbukti memiliki aktivitas sebagai antibakteri, antifungal, anti oksidan yang bermanfaat dalam bidang pengobatan.

\section{Kesimpulan}

Ekstrak metanol daun ulin (E. zwageri) dapat menghambat pertumbuhan bakteri patogen Gram positif dan Gram negatif seperti E. faecalis, S. aureus, S. typhi dan $E$. coli dengan respon hambatan pertumbuhan sedang hingga sangat kuat (7,33-22,67 mm). Ekstrak metanol daun ulin memiliki potensi untuk dikembangkan sebagai antibakteri alami. Hasil penelitian ini menambah bukti ilmiah aktivitas biologi dari ekstrak daun ulin sebagai antimikroba (antibakteri).

\section{Ucapan terima kasih}

Ucapan terima kasih diberikan kepada Fakultas Kehutanan Universitas Tanjungpura yang telah membiayai penelitian ini. Penelitian ini didanai oleh DIPA PNBP Fakultas Kehutanan dengan Surat Perjanjian Kontrak No. 558/UN22.7/PP/2018 tanggal 5 Maret 2018.

\section{Daftar Pustaka}

Ahmed N, Mahmood A, Tahir S, Bano A, Malik RN, Hassan S \& Ashraf A (2014). Ethnomedicinal knowledge and relative importance of indigenous medicinal plants of Cholistan desert, Punjab Province Pakistan. J. Ethnopharmarcol. 155: 1263-1275.

DOI: http://dx.doi.org/10.1016/j.jep.2014.07.007.

Al-Kattan MO \& Khayyat SA (2017). Phytochemical screening and antimicrobial activies of Costus speciosus and Sea Qust. Biomed. Res., 28 (1): 389-393. https://www.biomedres.info/biomedicalresearch/phytochemical-screening-andantimicrobial-activities-of-costus-speciosus-andsea-qust.pdf.

Allocati N, Masulli M, Alexeyev MF \& Di Ilio C (2013). Escherichia coli in Europe: An overview. Int. J. Environ. Res. Public Health. 10 (12): 6235-6254. DOI: http://dx.doi.org/10.3390/ijerph10126235.

Balouiri M, Sadiki M \& Ibnsouda SK. 2016. Metods for in vitro evaluating antimicrobial activity: A reviews. J. Pharmaceut. Anal. 6 (2): 71-79. DOI: http://dx.doi.org/10.1016/j.jpha.2015.11.005.

Coxti JB. (2019). The Role of Natural Products in Modern Drugs Discovery. An Acad Bras Cienc 91: e20190105. DOI: http://dx.doi.org/10.1590/0001$\underline{3765201920190105 .}$. 
Darussalam H (2016). Uji sensitivitas ekstrak kayu ulin (Eusideroxylon zwageri) terhadap pertumbuhan bakteri Staphylococcus aureus secara in vitro. Mahakam Med Lab Tech J. 1 (2): 81-90. $\underline{\text { http://ejournalanalis.poltekkes- }}$

kaltim.ac.id/ojs/index.php/Analis/article/view/6.

Demirel, Z., Yilmaz-Koz, F. F., Karabay-Yavasoglu, U. N., Ozdemir, G. \& Sukatar, A. (2009). Antimicrobial and antioxidant activity of brown algae from the Aegean Sea. Journal of the Serbian Chemical Society, 74, 619-628. http://dx.doi.org/10.2298/JSC0906619D.

Dzoyem JP, Melong R., Tsamo AT, Tchinda AT \& Kapche D (2017). Cytotoxicity, antimicrobial and antioxidant activity of eight compounds isolated from Entada abyssinica (Fabaceae). BMC Res. Notes., $\quad 10$ : 1-6. DOI: http://dx.doi.org/10.1186/s13104-017-2441-z.

Elisha IL, Jambalang AR., Botha FS, Buys EM, McGaw LJ. \& Eloff JN. (2017). Potency and selectivity indices of acetone leaf extracts of nine selected South African trees against six opportunistic Enterobacteriaceae isolates from commercial chicken eggs. BMC Complement. And Alt. Med., $17 \quad$ (1): $1-8$. DOI: http://dx.doi.org/10.1186/s12906-017-1597-3.

Grossman TH. (2016). Tetracycline Antibiotics and Resistance. Cold Spring Harb Perspect Med. 6(4): a025387.

DOI: http://dx.doi.org/10.1101/cshperspect.a025387.

Hidayat B., Yusro F. \& Mariani Y. (2019). Kemampuan Ekstrak Kulit Kayu Dua Spesies Macaranga Dalam Menghambat Pertumbuhan Bakteri Enterococcus faecalis. J. Borneo Akcaya. 5 (2). 95-109. http://jurnallitbang.kalbarprov.go.id:8088/index.php/litbang/a $\underline{\text { rticle/view/135 }}$

Khameneh B., Iranshahny M., Soheili V. \& Bazzaz BSF. (2019). A Review on Plant Antimicrobials: A Mechanistic Viewpoint. Antimicrobial Resistance and Infection Control. 8: 118. 1-28. DOI: http://doi.org/10.1186/s13756-019-0559-6.

Kurniawan E., Jekti DSD. \& Zulkif L. (2019). Aktivitas Antibakteri Ekstrak Metanol Batang Bidara Laut (Strychnos ligustriana) Terhadap Bakteri Patogen. J. Biologi Tropis. 19 (1): 61-69. http://dx.doi.org/10.29303/jbt.v19i1.1040.
Lehman KM \& Grabowicz (2019). Countering GramNegative Antibiotic Resistance: Recent Progress in Distrupting The Outer Membrane With Novel Therapeutics. Antibiotics. 8 (4): 1-18. DOI: http://dx.doi.org/10.3390/antibiotics8040163.

Lobritz MA., Belenky P., Porteb CB., Gutierrez A., Yang JH., Schwarz EG., Dwyerh DJ., Khalila AS. \& Collins JJ (2015). Antibiotic efficacy is linked to bacterial cellular respiration. PNAS. 112 (27): 8173-8180. DOI: $\quad$ http://dx.doi.org/ 10.1073/pnas.1509743112.

Mariani Y., Yusro F., Konishi Y., Taguchi T. \& Tominaga A. (2016). Regulatory effects of five medicinal plants used by Dayak Uud Danum in West Kalimantan Indonesia on the delayed-type hypersensitivity and the inflammation of human colon epithelial cells. Kuroshio Science. 10 (1): 59-71. http://kuroshio.cc.kochiu.ac.jp/repository/en/index.html.

Mathur R. (2013). Phytochemical and antimicrobial evaluation of plants extracts of Enicostemma hyssopifolium. J. Pharmacog. Phytochem, 2 (4): 30-36.

http://www.phytojournal.com/archives/?year=201 $3 \&$ vol=2\&issue $=4 \&$ ArticleId $=201$.

May KL \& Grabowicz M (2018). The Bacterial Outer Membrane is an Evolving Antibiotic Barrier. PNAS. $115 \quad$ (36): 8852-8854. DOI: http://dx.doi.org/10.1073/pnas.1812779115.

Mostafa AA., Al-Askar AA., Almaary KS., Dawoud TM., Sholkamy EN. \& Bakri MM (2018). Antimicrobial activity of some plant extracts against bacterial strains causing food poisoning diseases. Saudi J. Biol. Sciences. 25(2): 361366.

DOI: http://dx.doi.org/10.1016/j.sjbs.2017.02.004.

Nazzaro F., Fratianni F., De Martino L., Cappola R. \& De Feo V (2013). Effect of Essential oils on pathogenic bacteria. Pharmaceuticals 6 (12): 1451-1474.

DOI: http://dx.doi.org/10.3390/ph6121451.

Radulovic NS, Blagojevi PD., Stojanovic-Radic ZZ. \& Stojanovic NM (2013). Antimicrobial plant metabolites: Struktural diversity and mechanism of action. Curr. Med. Chem. 20 (7): 932-952. DOI: https://doi.org/10.2174/0929867311320070008. 
Prihatiningtyas W., Mariani Y., Oramahi HA., Yusro F. \& Sisillia L. (2018). Uji Aktivitas Antibakteri Ekstrak Etanol Kulit Batang Mangga Kweni (Mangifera odorata Griff) Terhadap Escherichia coli ATCC 25922 dan Staphylococcus aureus ATCC 25923). J. Tengkawang. 8 (2). 59-74. DOI: http://dx.doi.org/10.26418/jt.v8i2.

Primawati SN, Soelistya D. \& Zulkifli L. (2013). Profil Kualitatif Komponen Ekstrak Kunyit Putih (Curcuma zedoaria) dan Pengaruhnya Terhadap Profil Hematologi Mencit yang Diinfeksi Salmonella typhimurium. J. Biologi Tropis. 13 (2). $139-$ 146. DOI: http://dx.doi.org/10.29303/jbt.v13i2.147.

Pormohammad A., Nasiri MJ \& Azimi T. (2019). Prevalence of Antibiotic Resistance in Escherichia coli Strains Simultaneously Isolated from Humans, Animals, Food, and The Environment: a Systematic Review and MetaAnalysis. Infection and Drug Resistance. 12: 1181-1197. DOI: http://dx.doi.org/10.2147/IDR.5201324.

Raja RDA, Jeeva S, Prakash JW dan Marimuthu J (2011). Antibacterial activity of selected ethnomedicinal plants from South India. Asian Pacific J. Trop. Med., 11 (4): 375-378. DOI: http://dx.doi.org/10.1016/S22211691(11)60049-X.

Saleem M., Nazir M., Ali MS., Hussain H., Lee YS., Riaz N. \& Jabbar A. (2010). Antimicrobial natural products: An update on future antibiotic drug candidates. Natural product reports. 27. 23854. DOI: http://doi.org/10.1039/b916096e.

Sen, K., Berglund T., Soares MA., Taheri B., Ma Y., Khalil L., Fridge M., Lu J. \& Turner RJ. (2019). Antibiotic Resistance of $E$. coli Isolated from a Constructed Wetland Dominated by a Crow Roost, With Emphasis on ESBL and AmpC Containing E. coli. Front. Microbiol. 10: 1034. DOI: http://doi.org/10.3389/fmicb.2019.01034.

Wau, TPK., Izdihar DF, Gunawan K. \& Lubis YEP. (2019). Uji Efektivitas Ekstrak Buah Kesemek (Dyospiros kaki L.) Sebagai Antibakteri Terhadap Bakteri Escherichia coli. J. Biologi Tropis, 19 (2): 260-267. DOI: http://dx.doi.org/10.29303/jbt.v19i2.1049.

Wila H, Yusro F \& Mariani Y (2018). Skrining Fitokimia dan Aktivitas Antibakteri Ekstrak Kulit
Batang (Eusideroxylon zwageri) Terhadap Escherichia coli dan Salmonella tyhpi. J. $\begin{array}{lll}\text { Tengkawang. } & 8(1) \text { : } & 38-49 \text {. }\end{array}$ DOI: http://dx.doi.org/10.26418/jt.v8i1.30147. 